\section{Oxygen Uptake Rate and Heart Rate of Small Abalone Sulculus supertexta as Related to the Ambient Oxygen Concentration}

Short Paper

Yoshihachiro Nimura*1 and Hiroshi Yamakawa*2

(Received March 1, 1989)

The small abalone (tokobushi in Jpn.) Sulculus supertexta Haliotidae, has a good commercial value in Japan when purchased in living condition. Therefore, it is important to keep them alive until cooking. This work was intended to know the effect of ambient oxygen concentration on oxygen uptake rate and heart rate, because it was one of the most important environmental factors in stocking and transport in living condition.

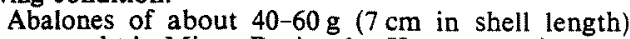
were caught in Miura Peninsula, Kanagawa, in summer, cleaned of the fouling organisms and kept in an aquarium supplied with running sea water for a few days, during which they were fed with kelp Ecklonia cava until one day before measurement. After measuring the weight and size, the part of shell which covered the heart was removed just to see the heart beat one day before measurement, because the opaque covering over the heart would make it difficult to see the heart beat long after opening the shell. The soft part of body was 73-78\% of the whole abalone, whose specific gravity was about 1.3 and used for the correction of respirometer volume. The temperature and chlorinity were steady during the experiment and changed less than $0.3^{\circ} \mathrm{C}$ and $0.3 \%$ respectively.

A $1.5 l$-sized glass chamber was used as a respirometer, which had a glass cover equipped with a stirrer and a Galvanic cell oxygen analyzer ${ }^{1)}$ which was calibrated by the Winkler's method everyday. ${ }^{2)}$ The chamber was immersed in a water bath of running sea water which also flowed through the chamber. After making an abalone rest in the chamber by keeping it there for more than $4 \mathrm{~h}$, the oxygen uptake rate was measured by the decrease in oxygen concentration in the closed chamber. The chamber was lit with a dim light during measurement.

The lower routine or standard oxygen uptake rate was about $27 \mathrm{ml} / \mathrm{h} / \mathrm{kg}$ of whole shell and the active rate could be more than $52 \mathrm{ml} / \mathrm{h} / \mathrm{kg}$ (Fig. 1); 36 and $69 \mathrm{~m} l / \mathrm{h} / \mathrm{kg}$ of soft part respectiviely. The active rate was similar to the data (probably lower routine rate) of the same species ${ }^{3)}$ and of Haliotis discus hannai ${ }^{\star 1}$ under similar condition.

The incipient lethal level of oxygen was about 1.5 $\mathrm{m} l \mathrm{O}_{2} / l$ or $30 \%$ of air-saturation at the temperature of about $25^{\circ} \mathrm{C}$; the chlorinity of water was about $18 \%$. Below this level, abalones often lifted the shell as if to assist gills easily in contacting more water. The left border of the area where the data of $\mathrm{O}_{2}$ uptake rate vs. $\mathrm{O}_{2}$ concentration scattered was a single line which seemed to pass the origin (Fig. 1) especially below the incipient lethal level; a part of the upper limit of activity scope as in the case of Japanese spiny lobster. ${ }^{2)}$ The $\mathrm{O}_{2}$ uptake by other than the abalone, probably by bacteria in water, was less than $3 \%$ that by the abalone. It was used for the correction.

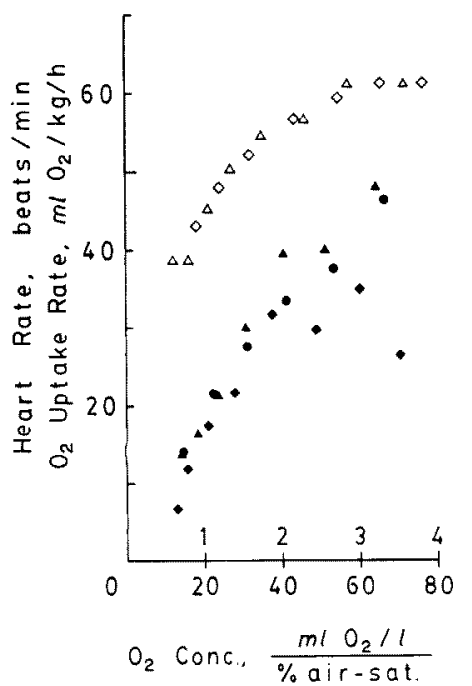

Fig. 1. $\mathrm{O}_{2}$ uptake rate and heart of Sulculus supertxta as related to the ambient oxygen concentration.

Open and solid symbols are the heart rate and $\mathrm{O}_{2}$ uptake rate respectively. Circles are for the specimen of $50 \mathrm{~g}$ in body weight (measured during 14:10-16:11), rhombi $51 \mathrm{~g}(21: 21-$

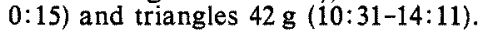

The heart rate was about $61 / \mathrm{min}$ and steady above $2.8 \mathrm{~m} l \mathrm{O}_{2} / l$ or $55 \%$ air-saturation, below which it decreased gradually (Fig. 1). The rate was higher than those of Haliotis gigantea, $H$. discus discus and $H$. madaka, probably because our abalones were smaller than the above mentioned abalones. ${ }^{b)}$ During the measurement the shells always attached to the wall. Any diurnal change was not observed in both rates in this experiment, though slightly lower rates of $\mathrm{O}_{2}$ uptake were measured at night $(20: 21-21: 46)$. A similar phenomenon on $\mathrm{O}_{2}$ uptake was also reported. ${ }^{3 \%}$

Since the $\mathrm{pH}$ and reserve $\mathrm{pH}$ were more than 8.0 at the end of measurement, the partial pressure of carbon dioxide was less than 0.5 Torr. ${ }^{8,7}$ The adverse effect was not expected.

\section{References}

1) K. H. Mancy and W.C. Westgarth: J. Water Poll. Cont. Fed., 34, 1037-1051 (1962).

2) Y. Nimura and M. Inoue: Nippon Suisan Gakkaishi, 35, 852-861 (1969).

3) T. Otaki, N. Yamada, and N. Uemura: Bull. Shizuoka Pref. Fish. Exp. Stn., 7, 73-78 (1974).

4) T. Tamura: Suisan Gaku Zasshi 43, 1-10 (1939).

5) T. Ino: The Abalone Science and its Propagation in Japan, Jpn. Ass. Consrv. Fish. Resoc., Tokyo, 1966, p. 31 .

6) J. M. Edmond and J. A. T. M. Gieskes: Geochim. Cosmochim. Acta, 34, 1261-1291 (1970).

7) R. F. Weiss: Mar. Chem., 2, 203-215 (1974).

*1 Department of Fisheries, University of Tokyo, Yayoi, Bunkyo, Tokyo 113, Japan (二村義八朗: 東京大学 農学部水産学科).

*2 Depertment of Aquatic Bioscience, Tokyo University of Fisheries, Konan, Minato, Tokyo 108, Japan (山川 紭: 東京水産大学資源育成学科). 